\title{
MicroRNAs: The Potential Biomarkers in Plant Stress Response
}

\author{
Sonali Bej, Jolly Basak* \\ Department of Biotechnology, Visva-Bharati, Santiniketan, India \\ Email: "jolly.basak@visva-bharati.ac.in
}

Received 20 January 2014; revised 24 February 2014; accepted 11 March 2014

Copyright (C) 2014 by authors and Scientific Research Publishing Inc.

This work is licensed under the Creative Commons Attribution International License (CC BY). http://creativecommons.org/licenses/by/4.0/

(c) (i) Open Access

\begin{abstract}
MicroRNAs (miRNAs) are endogenous small RNA regulatory molecules of approximate 20 - 24 nucleotides that are involved in regulating the intrinsic growth and development of organs in plants and animals as well as in maintaining the integrity of genomes. Past few years have witnessed an increase in research reports on the crucial role of miRNAs in plant stress response. Plant miRNAs regulate gene expression at the post-transcriptional level not only by suppression of mRNA translation but also by direct cleavage of the target mRNAs. This review starts with a brief overview on small RNAs including miRNAs, biogenesis of miRNA and focuses mainly on the various up- and down-regulated plant miRNAs under different biotic and abiotic stresses showing advancement of studies about miRNA and their stress regulation pathway. This review explores the emerging role of miRNAs as potential biomarkers in plant stress responses.
\end{abstract}

\section{Keywords}

MicroRNAs; Biomarker; Plant Stress Response

\section{Introduction}

Plants encounter various biotic and abiotic stresses which greatly affect their growth, development and yield. Since plants are sessile in nature so, they have evolved sophisticated mechanisms and efficient strategies to withstand the environmental stresses which are caused by various biotic or abiotic factors. The different mechanism of stress response contributes to stress resistance or stress tolerance at different morphological, biochemical and molecular levels [1]. The advancement of molecular biology research has shown that plants respond to stress not only at the mRNA or protein level but also at the post transcriptional level [2]. The small RNAs (sRNAs) are the bioregulators of plant stress response, regulates by transcriptional gene silencing (TGS)

"Corresponding author. 
or post-transcriptional gene silencing (PTGS) [3]. They perform gene silencing by RNA slicing [4], translational repression [5], histone modification and DNA methylation [6] [7]. Plant sRNAs are complex in nature and are classified on the basis of their biogenesis and the structure of the genomic loci [2]. sRNAs include microRNAs (miRNAs), small interfering RNAs (siRNAs), piwi interacting RNAs (piRNAs), small temporal RNAs (stRNAs), tiny non-coding RNAs (tncRNAs) and small modular RNAs (smRNAs). Among the complex variety of sRNAs, the microRNAs have been extensively characterized and found to be involved in various stress responses. They are encoded by MIR genes and are the key molecules in gene regulatory networks. Plant miRNA plays a vital role in development, physiological processes and stress responses. Many stress-regulated genes are found to be regulated by miRNAs. This review gives an overview of miRNAs, biogenesis of miRNAs and their roles as potential biomarkers in response to different biotic and abiotic stresses.

\section{MicroRNAs: Tiny Size yet Significant Role}

MicroRNAs are endogenous, single stranded non-coding regulatory RNAs of about 20 - 22 nt in size, are encoded by MIR genes. MicroRNA (miRNAs) lin-4 was first discovered in Caenorhabditis elegans in 1993 [8] [9] but the term microRNA was coined in 2001. They regulate various developmental and physiological processes [10]. Plant miRNAs are involved in developmental, metabolic processes, pattern formation, hormone regulation, biotic and abiotic stress response and in the pathway of self-regulation of the miRNA biogenesis [11].

\subsection{MicroRNA Biogenesis}

In the miRNA biogenesis pathway, the primary miRNAs (pri-miRNAs) containing a long sequence of several hundred nucleotides gets transcribed from MIR genes (nuclear-encoded) by the RNA polymerase II enzyme (Pol II) [12]. The pri-miRNA forms a characteristic hairpin structure. The pri-miRNAs are then processed into pre-miRNAs catalyzed by RNase-III like enzymes called Dicer-Like (DCL1) and HYPONASTIC LEAVES 1(HYL1) and SERRATE (SE) proteins [13]. The pre-miRNA hairpin precursor gets converted into a 20- to 22-nt miRNA/miRNA* duplex where methylation occurs at the 3' terminus by HUA ENHANCER 1 (HEN1). An exportin protein HASTY (HST1) exports it into the cytoplasm [13]. While entering the cytoplasm one of the duplex strands of miRNA is directed to the exosome and degraded by Small RNA Degrading Nuclease (SDN) [14]. The mature miRNA gets exposed to RNA-induced silencing complex (RISCs) complex. It gets incorporated into an ARGONAUTE (AGO) protein which guides it to bind to the target transcripts on basis of sequence complementarity.

\subsection{MicroRNA Mediated Regulation}

MicroRNAs regulates gene expression either by target mRNA cleavage or by translational repression [15] [16]. The perfect pairing between mRNA and miRNA results in target mRNA cleavage whereas imperfect pairing results in repression. Plant miRNA mediates target mRNA cleavage. Recently, researchers have found a new miRNA-mediated regulation known as miRNA mediated mRNA decay. When there is partial or little similarity between target mRNA and miRNA, the miRNA decays the target mRNA by removing its poly (A) tail, making it unstable leading to decay [15] [17] [18].

\subsection{MicroRNA Role in Plant Stress Response}

Recent advancement on miRNA research has revealed their vital role in post transcriptional regulation of genes which are necessary for stress response [1]. MicroRNAs (miRNAs) are differentially regulated under various stresses. Certain miRNAs are either under or over-expressed or new miRNAs gets synthesized under stress. In plants various biotic and abiotic stress-regulated miRNAs have been identified and characterized. Mostly miRNA target genes which encodes various transcriptional factors or functional enzymes having important roles in abiotic stress response.

\section{Potential miRNAs Biomarkers in Biotic Stress}

\subsection{Bacterial Infection}

In Arabidopsis, miR393 induced by a bacterial pattern associated molecular pattern (PAMP) was found to be the 
first miRNA to have role in plant antibacterial pattern triggered immunity (PTI) which negatively regulates the auxin signaling pathway [19]. Three miRNAs-miR160, miR167 and miR393 were found to be highly induced while miR825 was found to be down regulated after infection with Pseudomonas syringae pv. Tomato (DC3000hrcC) [20]. miR398 was also found to be down regulated on bacterial infection [21].

\subsection{Viral Infection}

Turnip mosaic virus (TuMV)-encoded RNA silencing repressor P1/HC-Pro has been found to have link with miR171. In Arabidopsis, P1/HC-Pro induced miR156 and miR164 was reported [22] [23]. A novel miRNA, brassica-miR1885 was found to be induced by TuMV infection [24]. In Tomato Leaf Curl Virus (ToLCV) miR159 was found up regulated while miR164 and miR171 was reported down regulated [25]. In a study, the miR159/319 and miR172 were found as potential biomarkers for Tomato leaf curl New Delhi virus (ToLCNDV) infection [26]. The role of individual miRNAs in response to viral infection has not yet been reported.

\subsection{Fungal Infection}

10 miRNA families were differentially expressed in response to infection by the rust fungus Cronartium quercuum $f$. sp. Fusiforme which causes fusiform rust disease in loblolly pine trees [27]. In powdery mildew disease of wheat caused by fungus Blumeria graminis $f$. sp.tritici (Bgt) have showed miRNA differential expression patterns- miR156, miR159, miR164, miR171 and miR396, were found to be down regulated while miR393, miR444 and miR827 were found to be up regulated [28]. Overexpression of Osa-miR7696 was found in rice blast infection [29].

\subsection{Nematode Infection}

In response to Heterodera schachtii infection, miR161, miR164, miR167a, miR172c, miR396a, b and miR398a were found down regulated in Arabidopsis [3] [30]. In soyabean, 101 miRNAs belonging to 40 families were found to be responsive to the infection of the soybean cyst nematode Heterodera glycines [31]. Table 1 lists important miRNAs differentially regulated under biotic stress conditions.

\section{Potential miRNAs Biomarkers in Abiotic Stress}

\subsection{Oxidative Stress}

The various environmental stresses-salinity, heavy metals, UV radiation, drought results in the rapid accumulation of reactive oxygen species (ROS) which includes superoxide radicals $\left(\mathrm{O}_{2}^{-}\right)$, hydrogen peroxide $\left(\mathrm{H}_{2} \mathrm{O}_{2}\right)$ and hydroxyl radicals $\left(\mathrm{OH}^{-}\right)$causes oxidative damage to the cells [32] [33].

Superoxide dismutases (SODs) convert the highly toxic superoxide radicals $\left(\mathrm{O}_{2}^{-}\right)$into less toxic hydrogen peroxide $\left(\mathrm{H}_{2} \mathrm{O}_{2}\right)$ [34]. The up regulation of the two $\mathrm{Cu}-\mathrm{Zn}$ superoxide dismutase (CSD) genes were reported to be dependent on miR398 levels. The cytosolic CSD1 and plastidic CSD2 both are targeted by miR398. Under stress, the expression of miR398 is down regulated resulting in increased accumulation of CSD1 and CSD2 mRNAs resulting in reduced accumulation of the highly toxic superoxide free radicals [21] [35]-[37] (Figure 1).

In Arabidopsis, the miR398 family is represented by two members with three loci-MIR398a, MIR398b and MIR398c [2] [38]-[40]. A study has identified seven $\mathrm{H}_{2} \mathrm{O}_{2}$-responsive miRNAs-miR169, miR397, miR528, miR827, miR1425, miR319a.2 and miR408-5p in rice seedlings [41].

\subsection{Drought Stress}

Drought the most dominant abiotic stress caused due to shortage in precipitation, soil water deficiency and excess of evaporation [42]. Plants tolerate drought conditions by enhanced water uptake, reduced water loss and by other mechanisms [32]. Recent studies on Triticum dicoccoides [43], cowpea [44], soybean [45], Phaseolus vulgaris [46], and tobacco [47] have found differential expression patterns of miRNAs in relation to drought stress. In Arabidopsis, miR396, miR168, miR167, miR165, miR319, miR159, miR394, miR156, miR393, miR171, miR158, and miR169 were found in response to drought [48] where miR393, miR319, and miR397 were up regulated [39]. miR393 up regulation is linked to drought stress, it decreases the TIR1 levels which is a positive regulator of growth and development and hence, results in retardation in growth. In rice, miR169g, miR171a and miR393 were found to be induced in response to dehydration [49]-[51]. It was found that the 
Table 1. The potential miRNA biomarkers identified in different biotic stress conditions.

\begin{tabular}{|c|c|c|c|c|}
\hline Type of Stress & miRNA biomarkers & Up regulated & Down regulated & References \\
\hline \multirow{5}{*}{ Virus } & miR171 & & $\Omega$ & Kasschau et al. 2003, Zhou and Luo 2013 \\
\hline & miR156, miR164 & $\Uparrow$ & \multirow{4}{*}{$\sqrt{ }$} & Kasschau et al. 2003 \\
\hline & miR159 & $\Uparrow$ & & N Tha. \\
\hline & miR164, miR171 & & & Naqvi et al. 2008 \\
\hline & miR1885 & 介 & & He et al. 2008 \\
\hline \multirow{4}{*}{ Bacteria } & miR393 & $\Uparrow$ & \multirow[b]{2}{*}{$\sqrt{2}$} & Navarro et al. 2006 \\
\hline & miR398 & & & Jagadeeswaran et al. 2009 \\
\hline & miR160, miR167 & 介 & & \multirow{2}{*}{ Fahlgren et al. 2007} \\
\hline & miR825 & & $\sqrt{ }$ & \\
\hline \multirow{3}{*}{ Fungi } & $\begin{array}{l}\text { miR156, miR159, } \\
\text { miR164, miR171, } \\
\text { miR396 }\end{array}$ & & l & \multirow[t]{2}{*}{ Xin et al.2010 } \\
\hline & $\begin{array}{l}\text { miR393, miR444, } \\
\text { miR827 }\end{array}$ & 介 & & \\
\hline & miR7696 & $\Uparrow$ & & Campo et al. 2013 \\
\hline Nematode & $\begin{array}{l}\text { miR161, miR164, } \\
\text { miR167a, miR172c, } \\
\text { miR396a,b, miR398a }\end{array}$ & & $\sqrt{ }$ & Hewezi et al. 2008 \\
\hline
\end{tabular}

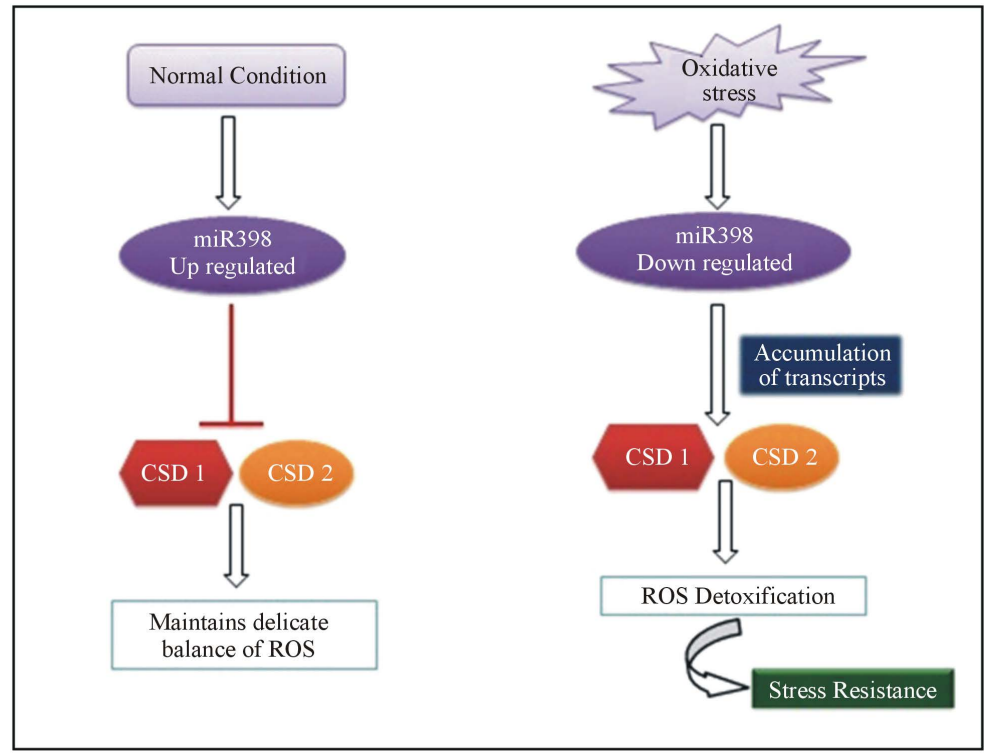

Figure 1. Role of miR398 in Oxidative stress.

accumulation of miR169g is transcriptionally regulated by CBF/DREBs transcription factors [37]. The result of a study of Genome wide profiling on drought-stressed rice found that 16 miRNAs - miR156, miR159, miR168, miR170, miR171, miR172, miR319, miR396, miR397, miR408, miR529, miR896, miR1030, miR1035, miR1050, miR1088, and miR1126 were down regulated and 14 miRNAs_miR159, miR169, miR171, miR319, miR395, miR474, miR845, miR851, miR854, miR896, miR901, miR903, miR1026 and miR1125 were up regulated in response to drought stress [50]. In Populus, miR171l-n, miR1445, miR1446a-e, miR1444a, miR1450, miR482.2, miR530a, miR827, miR1448 and miR1447 were found to be drought-responsive miRNAs [52]. In P.vulgaris, miRS1, miR1514a and miR2119 were found to be moderately up regulated whereas miR159.2, miR393 and miR2118 were found to be highly up regulated [46]. In Medicago truncatula, miR169 was found to be down regulated only in the roots and miR398 a, b and miR408 was strongly up regulated [53]. In a study on drought-resistant wild emmer wheat (Triticum turgidumssp. dicoccoides) 13 differentially regulated miRNAs were reported—miR1867, miR896, miR398, miR528, miR474, miR1450, miR396, miR1881, miR894, miR156, 
miR1432, miR166 and miR171 [54].

\subsection{Salinity Stress}

Salinity is the most serious abiotic stress. High salinity interferes with the plants' ability to uptake water causing similar conditions as drought [55]. In rice, three salt-inducible members of the miR169 family - miR169g, miR169n and miR169o and miR393 were found [56] [57] which specifically cleaves the NF-YA gene transcripts. In Arabidopsis, miR156, miR158, miR159, miR165, miR167, miR168, miR169, miR171, miR319, miR393, miR394, miR396 and miR397 were found to be up regulated while miR398 was down regulated [48]. In $P$. vulgaris miRS1 and miR159.2 were found to be highly upregulated [46]. In P. trichocarpa, miR530a, miR1445, miR1446a-e, miR1447 and miR171l-n were down regulated whereas miR482.2 and miR1450 were up regulated [16]. A recent microarray experiment on salt-tolerant and salt-sensitive Zea mays have identified 98 miRNAs from 27 families, miR156, miR164, miR167 and miR396 families members were reported to be down regulated, while miR162, miR168, miR395 and miR474 families were up regulated in salt-shocked maize roots [58].

\subsection{Cold Stress}

Studies have found miR319c as a biomarker in response to cold stress. It regulates the mRNA levels of TCP transcription factors [59] while miR397 targets the laccase family members LAC2, LAC4, and LAC17 which are important in the lignification process [60] [61]. The up regulated cold-stress responsive miRNAs-miR393, miR397b, miR402 and miR319c of Arabidopsis were first reported by Sunkar and Zhu in 2004. Many miRNAs were found to be significantly up-regulated-miR165/166, miR169, miR172, miR393, miR396, miR397 and miR408 while other miRNAs - miR156/157, miR159/319, miR164, miR394, miR398 were transiently regulated in response to cold stress [62]. miR397 and miR169 were found to up regulated in Arabidopsis [39] [48], Populus [16] and Brachypodium [63] while miR172 was up regulated in Arabidopsis and Brachypodium. In Populus, miR168 a, b and miR477 a, b were up regulated while miR156g-j, miR475a, b and miR476a were found to be down regulated [16]. In rice, 18 miRNAs_miR156k, miR166k, miR166m, miR167a/b/c, miR168b, miR169e, miR169f, miR169h, miR171a, miR535, miR319a/b, miR1884b, miR444a.1, miR1850, miR1868, miR1320, miR1435 and miR1876 were identified [64].

\subsection{UV Radiation}

UV radiation causes molecular damage at the DNA, RNA levels along with hyper accumulation of ROS [65]. In a study on Arabidopsis found 21 putative light-responsive miRNAs belonging to 11 different miRNA familiesmiR156, miR159, miR160, miR165/166, miR167, miR169, miR170, miR172, miR393, miR398 and miR401 [65]. In Populus tremula, 24 UV-B stress-responsive miRNAs (13 up-regulated and 11 down-regulated) were identified [66]. The three miRNA families-miR159, miR169, and miR393 were found to be up regulated in Arabidopsis but were down regulated in $P$. tremula, which suggests that UV-B radiation stress response maybe species-specific [66].

\subsection{Nutrient Stress}

miRNAs are vital in fine-regulation of nutrient homeostasis. According to different studies in Arabidopsis, potential biomarkers in response to nutrient stress such as in phosphate- miR399, sulfate- miR395, and coppermiR398 were reported [3]. miR399 partially controls phosphate equilibrium [3]. Under phosphate deficient condition the PHO2 gene which encodes an E2 ubiquitin conjugase related enzyme (E2-UBC24) is down- regulated and miR399 is up regulated [67]-[69]. The synthesis of miR399 is induced by PHOSPHATE STARVATION RESPONSE (PHR1) transcription factors which bind to GNATATNC cis elements for regulation of the phosphate-responsive genes [70]-[72]. The mature miR399 are synthesized in shoots and then moves via phloem to roots where it cleaves the targeted $\mathrm{PHO} 2$ transcripts [73] causing phosphate uptake by upregulating the phosphate transporters Pht1;8 and Pht1;9. As the phosphate balance improves, IPS1 (Induced by Phosphate Starvation) acts as target mimic of miR399 to prevent degradation of PHO2 transcripts. The miR399-PHO2IPS1 is thus an important cycle for Pi-deficiency signaling pathway in order to maintain phosphate homeostasis [37] (Figure 2). miR395 has been found to regulate the expression of low-affinity sulfate transporter AST68 (AtSULTR2;1) which functions in internal translocation of sulfate from roots to shoots and also targets ATP 
sulfurylases-APS1, APS3 and APS4 which functions in the sulfur assimilation pathway [38] [74]-[76]. Although the mechanism of how miR395 regulates in sulfate homeostasis has not yet been clarified. miR398 plays a vital role in Copper homeostasis. Under Cu-stressed conditions, the miR398 is up-regulated resulting in degradation of CSD1 and CSD2 transcripts to save $\mathrm{Cu}^{2+}$ for essential processes [36] [77]. Three conserved miRNA families-miR397, miR408 and miR857 were also found to be up-regulated under copper starvation as they targets transcripts which encodes Cu-containing laccase and plantacyanin [60]. The plantacyanin and LAC3, LAC12 and LAC13 transcripts are found to be targeted by miR408 and miR397 targets mRNAs of LAC2, LAC4 and LAC17 while miR857 targets the LAC7 transcript.

\subsection{Heat Stress}

Sudden increase in temperature (heat shock) leads to denaturation of proteins (enzymes) and interferes with cellular machineries to repair proteins and membranes. In response to heat stress, differential miRNA expression was observed in wheat. Among the 32 miRNA families found in wheat, nine were conserved heat responsive miRNAs. miR172 was found to be down regulated and other miRNAs-miR156, miR159, miR160, miR166, miR168, miR169, miR393 and miR827 were found to be up regulated in response to heat stress [28].

\subsection{Mechanical Stress}

miRNAs are regulated by mechanical stress which have functions in the structural and mechanical fitness of plants. In a study conducted on P. trichocarpa, it was observed that miR156, miR162, miR164, miR475, miR480 and miR481 were found to be down regulated but miR408 was up regulated. miR160 and miR172 were down regulated only in compressed-stressed tissue whereas miR168 was up regulated in tension-stressed tissues [3] [78].

\subsection{Phyto-Hormone-Mediated Stress}

Phyto-hormones such as Auxins, Abscisic acid (ABA), Ethylene and Jasmonate all are necessary for plant responses to various abiotic stresses [37]. In Arabidopsis, miR159 was found to regulate the ABA signaling pathway. Under dehydration stress, miR159 are induced by transcription factors Abscisic acid Insensitive-ABI3 and ABI5. The accumulated miR159 cleaves two MYB transcription factors-MYB101 and MYB33 resulting in hyposensitivity to ABA. The desentitization of the hormone signalling helps plants to resume growth [79]. In another study, the AUXIN RESPONSE FACTOR 10 (ARF10) transcription regulator was found to be targeted by miR160 in response to ABA stress during germination [80]. In Arabidopsis, miR160, miR393, miR397b, miR402, miR417 were found to be up regulated whereas miR169 and miR398 were found to be down regulated. In contrast, in rice miR319 was up regulated and miR167 and miR169 was down regulated [39] [80]-[84]. In

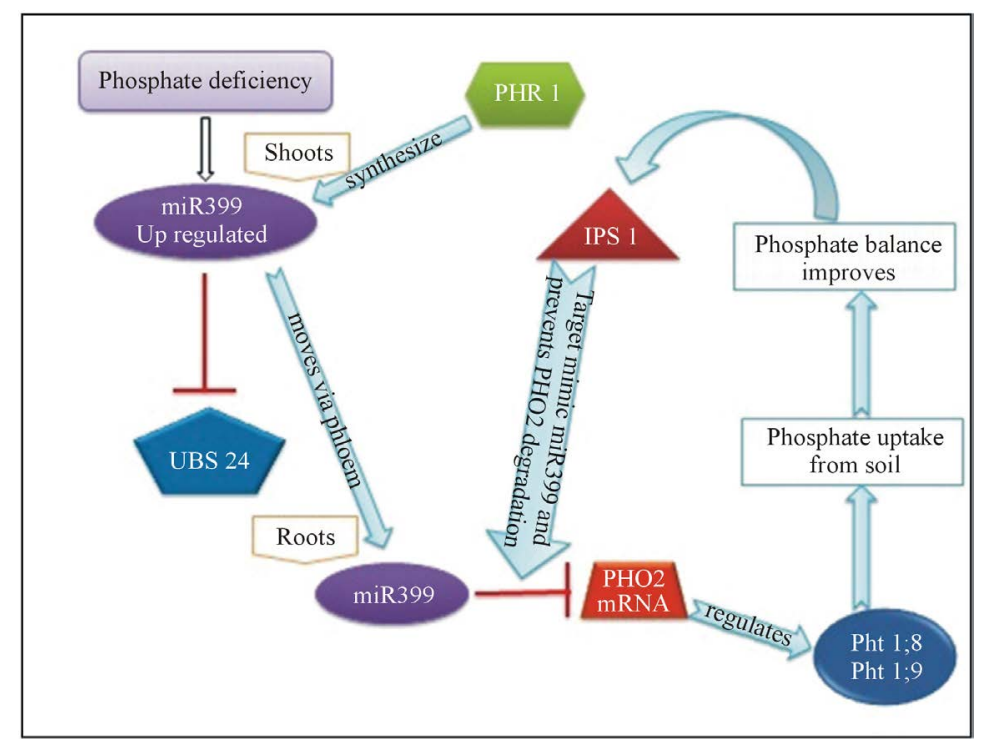

Figure 2. miR399 mediated phosphate homeostasis. 
Phaseolus vulgaris, miR159.2, miR393 and miR2118 were induced under ABA treatments whereas miRS1, miR1514 and miR2119 were moderately up regulated in response to ABA [46].

Auxin signaling mediated by miR393 which targets F-box auxin receptor gene- transport inhibitor response1 (TIR1) which proteolysis AUX/IAA proteins by SCF E3 ubiquitin ligases resulting in auxin-induced growth processes. miR393 mediated auxin signaling pathway is linked to biotic as well as abiotic stresses. Table 2 lists

Table 2. The potential miRNA biomarkers identified in different abiotic stress conditions.

\begin{tabular}{|c|c|c|c|c|}
\hline Type of Stress & miRNA biomarkers & Up regulated & Down regulated & References \\
\hline Oxidative stress & $\operatorname{miR398}$ & & $\mathfrak{l}$ & $\begin{array}{c}\text { Sunkar et al. 2006, Yamasaki et al. 2007, } \\
\text { Jagadeeswaran et al. 2009, } \\
\text { Kruszka et al. } 2012\end{array}$ \\
\hline \multirow{6}{*}{ Drought stress } & miR393, miR319, miR397 & & & Sunkar and Zhu 2004 \\
\hline & miR169g, miR171a & 个 & & $\begin{array}{l}\text { Zhao et al. 2007, Jian et al. 2010, } \\
\text { Zhou et al. } 2010\end{array}$ \\
\hline & $\begin{array}{l}\text { miR156,miR159, miR168, miR170, } \\
\text { miR171, miR172, miR319, } \\
\text { miR396,miR397, miR408, } \\
\text { miR529, miR896, miR1030, } \\
\text { miR1035, miR1050, miR1088, } \\
\text { miR1126 }\end{array}$ & & $\mathbb{1}$ & Zhou et al. 2010 \\
\hline & $\begin{array}{l}\text { miR159, miR169, miR171, } \\
\text { miR319, miR395, miR474, } \\
\text { miR845, miR851, miR854, } \\
\text { miR896, miR901, miR903, } \\
\text { miR1026, miR1125 }\end{array}$ & & & \\
\hline & miR159.2, miR393, miR2118 & & & Arenas-Huertero et al. 2009 \\
\hline & miR398 a, b, miR408 & & & Trindade et al. 2010 \\
\hline \multirow{3}{*}{ Salinity stress } & $\begin{array}{l}\text { miR169g, miR169n, miR169o, } \\
\text { miR393 }\end{array}$ & & & Zhao et al. 2009, Gao et al. 2011 \\
\hline & $\begin{array}{l}\text { miR156, miR158, miR159, } \\
\text { miR165, miR167, miR168, } \\
\text { miR169, miR171, miR319, } \\
\text { miR393, miR394, miR396, } \\
\text { miR397 }\end{array}$ & & & Liu et al. 2008 \\
\hline & $\operatorname{miR398}$ & & $\mathfrak{l}$ & \\
\hline \multirow[t]{2}{*}{ Cold stress } & $\begin{array}{l}\text { miR165/166, miR169, miR172, } \\
\text { miR393, miR396, miR397, } \\
\text { miR408, miR168a,b and } \\
\text { miR477a,b, miR319c }\end{array}$ & & & $\begin{array}{l}\text { Zhou et al. 2008, Lu et al. 2008, } \\
\text { Palatnik et al. } 2007\end{array}$ \\
\hline & miR156g-j, miR475a,b, miR476a & & I & Lu et al. 2008 \\
\hline \multirow[b]{2}{*}{ UV stress } & miR159, miR169, miR393 & & & Jia et al. 2009a \\
\hline & $\begin{array}{l}\text { miR156, miR159, } \\
\text { miR160, miR165/166, miR167, } \\
\text { miR169, miR170, miR172, } \\
\text { miR393, miR398, miR401 }\end{array}$ & 介 & & Zhou et al. 2007b \\
\hline Phosphate stress & miR399 & $\Uparrow$ & & $\begin{array}{c}\text { Fujii et al. 2005, Chiou et al. 2006, } \\
\text { Bari et al. } 2006\end{array}$ \\
\hline Copper stress & $\operatorname{miR395}$ & 介 & & $\begin{array}{l}\text { Jones-Rhoades and Bartel 2004, Allen et al. } \\
\text { 2005, Sunkar et al. 2007, Huang et al. } 2010 \text {, } \\
\text { Liang and Yu } 2010\end{array}$ \\
\hline \multirow{2}{*}{ Sulfate stress } & $\operatorname{miR398}$ & 介 & & Yamasaki et al. 2007, Beauclair et al. 2010 \\
\hline & miR397, miR408, miR857 & 介 & & Abdel-Ghany and Pilon 2008 \\
\hline \multirow[t]{2}{*}{ Mechanical stress } & $\begin{array}{l}\text { miR156, miR162, miR164, } \\
\text { miR475, miR480, miR481, } \\
\text { miR160, miR172 }\end{array}$ & & I & Lu et al. 2005, Khraiwesh et al. 2012 \\
\hline & miR408, miR168 & 刃 & & Lu et al. 2005, Khraiwesh et al. 2012 \\
\hline \multirow[t]{2}{*}{ Heat stress } & $\begin{array}{l}\text { miR156, miR159, miR160, } \\
\text { miR166, miR168, } \\
\text { miR169, miR393, miR827 }\end{array}$ & 介 & & Xin et al. 2010 \\
\hline & $\operatorname{miR} 172$ & & $\Omega$ & \\
\hline
\end{tabular}


important miRNAs differentially regulated under abiotic stress conditions.

\section{Conclusion}

Ten years after the discovery of miRNA in C. elegans, it was identified in Arabidopsis. Since, then a lot of research has undergone to identify the different miRNAs and their functions. They act as ribo-regulators of gene expression in both plants and animals. The miRBase is the primary repository and database resource for all the published miRNA data. The current release-20 contains 24,521 entries of precursor miRNA in 206 species, which clearly shows the explosive increase in number of miRNA identified in recent times. miRNA are crucial components of stress regulatory networks. The complex trait of plant stress tolerance can be understood by more extensive studies on miRNA-mediated gene regulation. The miRNA profiling of different plant species exposed to the different environmental stresses can help to identify and characterize new miRNA biomarkers. The data obtained from the characterization of the new miRNAs biomarkers and their stress regulatory networks will help in designing tools to improve plant stress resistance or stress tolerance against various stresses. But still most of the miRNA functions are unknown, which creates a large gap between identified miRNAs and their functions. Moreover, the miRNA so far studied for plant stress response has only been limited to some specific plants. So, the current research needs more identification and characterization of plant miRNAs biomarkers from various important plant species.

\section{References}

[1] Covarrubias, A.A. and Reyes, J.L. (2010) Post-Transcriptional Gene Regulation of Salinity and Drought Responses by Plant MicroRNAs. Plant, Cell and Environment, 33, 481-489. http://dx.doi.org/10.1111/j.1365-3040.2009.02048.x

[2] Phillips, J.R., Dalmay, T. and Bartels, D. (2007) The Role of Small RNAs in Abiotic Stress. FEBS Letters, 581, 35923597. http://dx.doi.org/10.1016/j.febslet.2007.04.007

[3] Khraiwesh, B., Zhu, J.K. and Zhu, J. (2012) Role of miRNAs and siRNAs in Biotic and Abiotic Stress Responses of Plants. Biochimica et Biophysica Acta, 1819, 137-148. http://dx.doi.org/10.1016/j.bbagrm.2011.05.001

[4] Baumberger, N. and Baulcombe, D.C. (2005) Arabidopsis ARGONAUTE1 Is an RNA Slicer That Selectively Recruits MicroRNAs and Short Interfering RNAs. Proceedings of the National Academy of Sciences of the United States of America, 102, 11928-11933. http://dx.doi.org/10.1073/pnas.0505461102

[5] Lanet, E., Delannoy, E., Sormani, R., Floris, M., Brodersen, P., Crete, P., Voinnet, O. and Robaglia, C. (2009) Biochemical Evidence for Translational Repression by Arabidopsis MicroRNAs. Plant Cell, 21, 1762-1768. http://dx.doi.org/10.1105/tpc.108.063412

[6] Khraiwesh, B., Arif, M.A., Seumel, G.I., Ossowski, S., Weigel, D., Reski, R. and Frank, W. (2010) Transcriptional Control of Gene Expression by MicroRNAs. Cell, 140, 111-122. http://dx.doi.org/10.1016/j.cell.2009.12.023

[7] Schramke, V. and Allshire, R. (2004) Those Interfering Little RNAs: Silencing and Eliminating Chromatin. Current Opinion in Genetics \& Development, 14, 174-180. http://dx.doi.org/10.1016/j.gde.2004.02.006

[8] Lee, R.C., Feinbaum, R.L. and Ambros, V. (1993) The C. elegans Heterochronic Gene Lin-4 Encodes Small RNAs with Antisense Complementarity to Lin-14. Cell, 75, 843-854. http://dx.doi.org/10.1016/0092-8674(93)90529-Y

[9] Reinhart, B.J., Weinstein, E.G., Rhoades, M.W., Bartel, B. and Bartel, D.P. (2002) MicroRNAs in Plants. Genes and Development, 16, 1616-1626. http://dx.doi.org/10.1101/gad.1004402

[10] He, L. and Hannon, G.J. (2004) MicroRNAs: Small RNAs with a Big Role in Gene Regulation. Nature Reviews Genetics, 5, 522-531. http://dx.doi.org/10.1038/nrg1379

[11] Jones-Rhoades, M.W., Bartel, D.P. and Bartel, B. (2006) MicroRNAs and Their Regulatory Roles in Plants. Annual Review of Plant Biology, 57, 19-53. http://dx.doi.org/10.1146/annurev.arplant.57.032905.105218

[12] Lee, Y., Kim, M., Han, J., Yeom, K.H., Lee, S., Baek, S.H. and Kim, V.N. (2004) MicroRNA Genes Are Transcribed by RNA Polymerase II. EMBO Journal, 23, 4051-4060. http://dx.doi.org/10.1038/sj.emboj.7600385

[13] Park, M.Y., Wu, G., Gonzalez-Sulser, A., Vaucheret, H. and Poethig, R.S. (2005) Nuclear Processing and Export of MicroRNAs in Arabidopsis. Proceedings of the National Academy of Sciences of the United States of America, 102, 3691-3696. http://dx.doi.org/10.1073/pnas.0405570102

[14] de Lima, J.C., Loss-Morais, G. and Margis, R. (2012) MicroRNAs Play Critical Roles during Plant Development and in Response to Abiotic Stresses. Genetics and Molecular Biology, 35, 1069-1077.

[15] Guleria, P., Mahajan, M., Bhardwaj, J. and Yadav, S. (2011) Plant Small RNAs: Biogenesis, Mode of Action and Their Roles in Abiotic Stresses. Genomics Proteomics Bioinformatics, 9, 183-199. 
http://dx.doi.org/10.1016/S1672-0229(11)60022-3

[16] Lu, X.Y. and Huang, X.L. (2008) Plant miRNAs and Abiotic Stress Responses. Biochemical and Biophysical Research Communications, 368, 458-462. http://dx.doi.org/10.1016/j.bbrc.2008.02.007

[17] Jing, Q., et al. (2005) Involvement of MicroRNA in AU-Rich Element Mediated mRNA Instability. Cell, 120, 623-634. http://dx.doi.org/10.1016/j.cell.2004.12.038

[18] Wu, L.G., et al. (2006) MicroRNAs Direct Rapid Deadenylation of mRNA. Proceedings of the National Academy of Sciences of the United States of America, 103, 4034-4039. http://dx.doi.org/10.1073/pnas.0510928103

[19] Navarro, L., Dunoyer, P., Jay, F., Arnold, B., Dharmasiri, N., et al. (2006) A Plant miRNA Contributes to Antibacterial Resistance by Repressing Auxin Signaling. Science, 312, 436-39. http://dx.doi.org/10.1073/pnas.0510928103

[20] Fahlgren, N., Howell, M.D., Kasschau, K.D., Chapman, E.J., Sullivan, C.M., Cumbie, J.S., Givan, S.A., Law, T.F., Grant, S.R., Dangl, J.L., Carrington, J.C. (2007) Highthroughput Sequencing of Arabidopsis MicroRNAs: Evidence for Frequent Birth and Death of MIRNA Genes. PLoS ONE, 2, Article ID: e219. http://dx.doi.org/10.1371/journal.pone.0000219

[21] Jagadeeswaran, G., Saini, A., Sunkar, R. (2009) Biotic and Abiotic Stress Down-Regulate miR398 Expression in Arabidopsis. Planta, 229, 1009-1014. http://dx.doi.org/10.1007/s00425-009-0889-3

[22] Kasschau, K.D., Xie, Z., Allen, E., Llave, C., Chapman, E.J., Krizan, K.A. and Carrington, J.C. (2006) P1/HC-Pro, a Viral Suppressor of RNA Silencing, Interferes with Arabidopsis Development and miRNA Function. Developmental Cell, 4, 205-217. http://dx.doi.org/10.1016/S1534-5807(03)00025-X

[23] Zhou, M. and Luo, H. (2013) MicroRNA-Mediated Gene Regulation: Potential Applications for Plant Genetic Engineering. Plant Molecular Biology, 83, 59-75. http://dx.doi.org/10.1007/s11103-013-0089-1

[24] He, X.F., Fang, Y.Y., Feng, L. and Guo, H.S. (2008) Characterization of Conserved and Novel MicroRNAs and Their Targets, Including a TuMV-Induced TIR-NBS-LRR Class R Gene-Derived Novel miRNA in Brassica. FEBS Letters, 582, 2445-2452. http://dx.doi.org/10.1016/j.febslet.2008.06.011

[25] Naqvi, A.R., Choudhury, N.R., Haq, Q.M.R. and Mukherjee, S.K. (2008) MicroRNAs as Biomarkers in Tomato Leaf Curl Virus (ToCLV). Nucleic Acids Symposium Series No. 52, 507-508.

[26] Naqvi, A.R., Haq, Q.M.R. and Mukherjee, S.K. (2010) MicroRNA Profiling of Tomato Leaf Curl New Delhi Virus (Tolcndv) Infected Tomato Leaves Indicates That Deregulation of mir159/319 and mir172 Might Be Linked with Leaf Curl Disease. Virology Journal, 7, 281. http://dx.doi.org/10.1186/1743-422X-7-281

[27] Lu, S., Sun, Y.H., Amerson, H. and Chiang, V.L. (2007) MicroRNAs in Loblolly Pine (Pinustaeda L.) and Their Association with Fusiform Rust Gall Development. The Plant Journal, 51, 1077-1098. http://dx.doi.org/10.1111/j.1365-313X.2007.03208.X

[28] Xin, M., Wang, Y., Yao, Y., Xie, C., Peng, H., Ni, Z. and Sun, Q. (2010) Diverse Set of MicroRNAs Are Responsive to Powdery Mildew Infection and Heat Stress in Wheat (Triticumaestivum L.). BMC Plant Biology, 10, 123. http://dx.doi.org/10.1186/1471-2229-10-123

[29] Campo, S., Peris-Peris, C., Sire', C., Moreno, A.B., Donaire, L., Zytnicki, M., Notredame, C., Llave, C. and San Segundo, B. (2013) Identification of a Novel MicroRNA (miRNA) from Rice That Targets an Alternatively Spliced Transcript of the Nramp6 (Natural Resistance Associated Macrophage Protein 6) Gene Involved in Pathogen Resistance. New Phytologist, 199, 212-227. http://dx.doi.org/10.1111/nph.12292

[30] Hewezi, T., Howe, P., Maier, T.R. and Baum, T.J. (2008) Arabidopsis Small RNAs and Their Targets during Cyst Nematode Parasitism. Mol Plant Microbe Interact, 21, 1622-1634. http://dx.doi.org/10.1094/MPMI-21-12-1622

[31] Li, X., Wang, X., Zhang, S., Liu, D., Duan, Y. and Dong, W. (2012) Identification of Soybean MicroRNAs Involved In Soybean Cyst Nematode Infection by Deep Sequencing. PLoS ONE, 7, Article ID: e39650. http://dx.doi.org/10.1371/journal.pone.0039650

[32] Bartels, D. and Sunkar, R. (2005) Drought and Salt Tolerance in Plants. Critical Reviews in Plant Sciences, $24,23-58$. http://dx.doi.org/10.1080/07352680590910410

[33] Mittler, R. (2002) Oxidative Stress Antioxidants and Stress Tolerance. Trends Plant Science, 7, 405-410. http://dx.doi.org/10.1016/S1360-1385(02)02312-9

[34] Fridovich, I. (1995) Superoxide Radical and Superoxide Dismutases. Annual Review of Biochemistry, 64, 97-112. http://dx.doi.org/10.1146/annurev.bi.64.070195.000525

[35] Sunkar, R., Kapoor, A. and Zhu, J.K. (2006) Posttranscriptional Induction of Two Cu/Zn Superoxide Dismutase Genes in Arabidopsis Is Mediated by Downregulation of miR398 and Important for Oxidative Stress Tolerance. Plant Cell, 18, 2051-2065. http://dx.doi.org/10.1105/tpc.106.041673

[36] Yamasaki, H., Abdel-Ghany, S.E., Cohu, C.M., Kobayashi, Y., Shikanai, T. and Pilon, M. (2007) Regulation of Copper Homeostasis by Micro-RNA in Arabidopsis. Journal of Biological Chemistry, 282, 16369-16378. 
http://dx.doi.org/10.1074/jbc.M700138200

[37] Kruszka, K., Pieczynskia, M., Windelsb, D., Bielewicza, D., Jarmolowskia, A., Kulinskaa, Z.S. and Vazquezb, F. (2012) Role of MicroRNAs and Other sRNAs of Plants in Their Changing Environments. Journal of Plant Physiology, 169, 1664-1672. http://dx.doi.org/10.1016/j.jplph.2012.03.009

[38] Jones-Rhoades, M.W. and Bartel, D.P. (2004) Computational Identification of Plant MicroRNAs and Their Targets, Including a Stress-Induced miRNA. Molecular Cell, 14, 787-799. http://dx.doi.org/10.1016/j.molcel.2004.05.027

[39] Sunkar, R. and Zhu, J.K. (2004) Novel Stress-Regulated MicroRNAs and Other Small RNAs from Arabidopsis. Plant Cell, 16, 2001-2019. http://dx.doi.org/10.1105/tpc.104.022830

[40] Bonnet, E., Wuyts, J., Rouze, P. and Van de Peer, Y. (2004) Detection of 91 Potential Conserved Plant MicroRNAs in Arabidopsis thaliana and Oryza sativa Identifies Important Target Genes. Proceedings of the National Academy of Sciences of the United States of America, 101, 11511-11516. http://dx.doi.org/10.1073/pnas.0404025101

[41] Li, T., Li, H., Zhang, Y.X. and Liu, J.Y. (2010) Identification and Analysis of Seven $\mathrm{H}_{2} \mathrm{O}_{2}$-Responsive miRNAs and 32 New miRNAs in the Seedlings of Rice (Oryza sativa L. ssp. Indica). Nucleic Acids Research, 39, 2821-2833.

[42] Shukla, L.I., Chinnusamy, V. and Sunkar, R. (2008) The Role of MicroRNAs and Other Endogenous Small RNAs in Plant Stress Responses. Biochimica et Biophysica Acta, 1779, 743-748.

[43] Kantar, M., Lucas, S.J. and Budak, H. (2011) miRNA Expression Patterns of Triticumdicoccoides in Response to Shock Drought Stress. Planta, 233, 471-484. http://dx.doi.org/10.1007/s00425-010-1309-4

[44] Barrera-Figueroa, B.E., Gao, L., Diop, N.N., Wu, Z., Ehlers, J.D., Roberts, P.A., Close, T.J., Zhu, J.K. and Liu, R.Y. (2011) Identification and Comparative Analysis of Drought-Associated MicroRNAs in Two Cowpea Genotypes. BMC Plant Biology, 11, 127. http://dx.doi.org/10.1186/1471-2229-11-127

[45] Kulcheski, F.R., de Oliveira, L.F., Molina, L.G., Almerao, M.P., Rodrigues, F.A., Marcolino, J., et al. (2011) Identification of Novel Soybean MicroRNAs Involved in Abiotic and Biotic Stresses. BMC Genomics, 12, 307. http://dx.doi.org/10.1186/1471-2164-12-307

[46] Arenas-Huertero, C., Pérez, B., Rabanal, F., Blanco-Melo, D., De la Rosa, C., Estrada-Navarrete, G., Sanchez, F., Covarrubias, A. and Reyes, J. (2009) Conserved and Novel miRNAs in the Legume Phaseolus vulgaris in Response to Stress. Plant Molecular Biology, 70, 385-401. http://dx.doi.org/10.1007/s11103-009-9480-3

[47] Frazier, T.P., Sun, G., Burklew, C.E. and Zhang, B. (2011) Salt and Drought Stresses Induce the Aberrant Expression of MicroRNA Genes in Tobacco. Molecular Biotechnology, 49, 159-165. http://dx.doi.org/10.1007/s12033-011-9387-5

[48] Liu, H.H., Tian, X., Li, Y.J., Wu, C.A. and Zheng, C.C. (2008) Microarray-Based Analysis of Stress-Regulated MicroRNAs in Arabidopsis thaliana. RNA, 14, 836-843. http://dx.doi.org/10.1261/rna.895308

[49] Zhao, B.T., Liang, R.Q., Ge, L.F., Li, W., Xiao, H.S., Lin, H.X., Ruan, K.C. and Jin, Y.X. (2007) Identification of Drought-Induced MicroRNAs in Rice. Biochemical and Biophysical Research Communications, 354, 585-590. http://dx.doi.org/10.1016/j.bbrc.2007.01.022

[50] Zhou, L., Liu, Y., Liu, Z., Kong, D., Duan, M. and Luo, L. (2010) Genome-Wide Identification and Analysis of Drought-Responsive MicroRNAs in Oryza sativa. Journal of Experimental Botany, 61, 4157-4168. http://dx.doi.org/10.1093/jxb/erq237

[51] Jian, X., Zhang, L., Li, G., Zhang, L., Wang, X., Cao, X., Fang, X.H. and Chen, F. (2010) Identification of Novel Stress Regulated MicroRNAs from Oryza sativa L. Genomics, 95, 47-55. http://dx.doi.org/10.1016/j.ygeno.2009.08.017

[52] Lu, S.F., Sun, Y.H. and Chiang, V.L. (2008) Stress-Responsive MicroRNAs in Populus. Plant Journal, 55, $131-151$. http://dx.doi.org/10.1111/j.1365-313X.2008.03497.x

[53] Trindade, I., Capitão, C., Dalmay, T., Fevereiro, M.P. and Santos, D.M. (2010) miR398 and miR408 Are Up-Regulated in Response to Water Deficit in Medicago truncatula. Planta, 231, 705-716. http://dx.doi.org/10.1007/s00425-009-1078-0

[54] Kantar, M., Lucas, S. and Budak, H. (2011) miRNA Expression Patterns of Triticum dicoccoides in Response to Shock Drought Stress. Planta, 233, 471-484.

[55] Munns, R. (2005) Genes and Salt Tolerance: Bringing Them Together. New Phytologist, 167, 645-663. http://dx.doi.org/10.1111/j.1469-8137.2005.01487.x

[56] Zhao, B.T., Ge, L.F., Liang, R.Q., Li, W., Ruan, K.C., Lin, H.X. and Jin, Y.X. (2009) Members of miR-169 Family Are Induced by High Salinity and Transiently Inhibit the NF-YA Transcription Factor. BMC Molecular Biology, 10, 29. http://dx.doi.org/10.1186/1471-2199-10-29

[57] Gao, P., Bai, X., Yang, L., Lv, D., Pan, X., Li, Y., Cai, H., Ji, W., Chen, Q. and Zhu, Y.M. (2011) osa-MIR393: A Salinity- and Alkaline Stress-Related MicroRNA Gene. Molecular Biology Reports, 38, 237-242. http://dx.doi.org/10.1007/s11033-010-0100-8 
[58] Ding, D., Zhang, L., Wang, H., Liu, Z., Zhang, Z. and Zheng, Y. (2009) Differential Expression of miRNAs in Response to Salt Stress in Maize Roots. Annals of Botany, 103, 29-38. http://dx.doi.org/10.1093/aob/mcn205

[59] Palatnik, J.F., Wollmann, H., Schommer, C., Schwab, R., Boisbouvier, J., Rodriguez, R., Warthmann, N., Allen, E., Dezulian, T., Huson, D., Carrington, J.C. and Weigel, D. (2007) Sequence and Expression Differences Underlie Funtional Specialization of Arabidopsis MicroRNAs miR159 and miR319. Developmental Cell, 13, 115-125. http://dx.doi.org/10.1016/j.devcel.2007.04.012

[60] Abdel-Ghany, S.E. and Pilon, M. (2008) MicroRNA-Mediated Systemic Down-Regulation of Copper Protein Expression in Response to Low Copper Availability in Arabidopsis. Journal of Biological Chemistry, 283, 15932-15945. http://dx.doi.org/10.1074/jbc.M801406200

[61] Bosch, M., Mayer, C.D., Cookson, A. and Donnison, I.S. (2011) Identification of Genes Involved in Cell Wall Biogenesis in Grasses by Differential Gene Expression Profiling of Elongating and Non-Elongating Maize Internodes. Journal of Experimental Botany, 62, 3545-3561. http://dx.doi.org/10.1093/jxb/err045

[62] Zhou, X., Wang, G., Sutoh, K., Zhu, J.K. and Zhang, W.X. (2008) Identification of Cold-Inducible MicroRNAs in Plants by Transcriptome Analysis. Biochimica et Biophysica Acta, 1779, 780-788. http://dx.doi.org/10.1016/j.bbagrm.2008.04.005

[63] Zhang, J., Xu, Y., Huan, Q. and Chong, K. (2009) Deep Sequencing of Brachypodium Small RNAs at the Global Genome Level Identifies MicroRNAs Involved in Cold Stress Response. BMC Genomics, 10, 449. http://dx.doi.org/10.1186/1471-2164-10-449

[64] Lv, D.K., Bai, X., Li, Y., Ding, X.D., Ge, Y., Cai, H., Ji, W., Wu, N. and Zhu, Y.M. (2010) Profiling of Cold-StressResponsive miRNAs in Rice by Microarrays. Gene, 459, 39-47. http://dx.doi.org/10.1016/j.gene.2010.03.011

[65] Zhou, X.F., Wang, G.D. and Zhang, W.X. (2007) UV-B Responsive MicroRNA Genes in Arabidopsis thaliana. Molecular Systems Biology, 3, 103.

[66] Jia, X., Ren, L., Chen, Q.J., Li, R. and Tang, G. (2009) UV-B-Responsive MicroRNAs in Populus tremula. Journal of Plant Physiology, 166, 2046-2057. http://dx.doi.org/10.1016/j.jplph.2009.06.011

[67] Fujii, H., Chiou, T.J., Lin, S.I., Aung, K. and Zhu, J.K. (2005) A miRNA Involved in Phosphate Starvation Response in Arabidopsis. Current Biology, 15, 2038-2043. http://dx.doi.org/10.1016/j.cub.2005.10.016

[68] Chiou, T., Aung, K., Lin, S., Wu, C., Chiang, S. and Su, C. (2006) Regulation of Phosphate Homeostasis by MicroRNA in Arabidopsis. Plant Cell, 18, 412-421. http://dx.doi.org/10.1105/tpc.105.038943

[69] Bari, R., Datt Pant, B., Stitt, M. and Scheible, W.R. (2006) $\mathrm{PHO}_{2}$, MicroRNA399, and PHR1 Define a Phosphate-Signaling Pathway in Plants. Plant Physiology, 141, 988-999. http://dx.doi.org/10.1104/pp.106.079707

[70] Chiou, T.J. (2007) The Role of MicroRNAs in Sensing Nutrient Stress. Plant, Cell \& Environment, 30, 323-332. http://dx.doi.org/10.1111/j.1365-3040.2007.01643.x

[71] Franco-Zorrilla, J.M., González, E., Bustos, R., Linhares, F., Leyva, A. and Paz-Ares, J. (2004) The Transcriptional Control of Plant Responses to Phosphate Limitation. Journal of Experimental Botany, 55, 285-293. http://dx.doi.org/10.1093/jxb/erh009

[72] Rubio, V., Linhares, F., Solano, R., Martin, A.C., Iglesias, J., Leyva, A. and Paz-Ares, J. (2001) A Conserved MYB Transcription Factor Involved in Phosphate Starvation Signaling both in Vascular Plants and in Unicellular Algae. Genes \& Development, 15, 2122-2133. http://dx.doi.org/10.1101/gad.204401

[73] Pant, B.D., Buhtz, A., Kehr, J. and Scheible, W.R. (2008) MicroRNA399 Is a Long-Distance Signal for the Regulation of Plant Phosphate Homeostasis. Plant Journal, 53, 31-38. http://dx.doi.org/10.1111/j.1365-313X.2007.03363.x

[74] Liang, G. and Yu, D. (2010) Reciprocal Regulation among miR395 APS and SULTR2;1 in Arabidopsis thaliana. Plant Signaling \& Behavior, 5, 1257-1259. http://dx.doi.org/10.4161/psb.5.10.12608

[75] Allen, E., Xie, Z., Gustafson, A.M. and Carrington, J.C. (2005) MicroRNA-Directed Phasing during Transacting siRNA Biogenesis in Plants. Cell, 121, 207-221. http://dx.doi.org/10.1016/j.cell.2005.04.004

[76] Sunkar, R., Chinnusamy, V., Zhu, J. and Zhu, J.K. (2007) Small RNAs as Big Players in Plant Abiotic Stress Responses and Nutrient Deprivation. Trends in Plant Science, 12, 301-309. http://dx.doi.org/10.1016/j.tplants.2007.05.001

[77] Beauclair, L., Yu, A. and Bouche, N. (2010) MicroRNA-Directed Cleavage and Translational Repression of the Copper Chaperone for Superoxide Dismutase mRNA in Arabidopsis. Plant Journal, 62, 454-462. http://dx.doi.org/10.1111/j.1365-313X.2010.04162.x

[78] Lu, S.F., Sun, Y.H., Shi, R., Clark, C., Li, L.G. and Chiang, V.L. (2005) Novel and Mechanical Stress Responsive MicroRNAs in Populustrichocarpa that Are Absent from Arabidopsis. Plant Cell, 17, 2186-2203. http://dx.doi.org/10.1105/tpc.105.033456

[79] Reyes, J.L. and Chua, N.H. (2007) ABA Induction of miR159 Controls Transcript Levels of Two MYB Factors during 
Arabidopsis Seed Germination. Plant Journal, 49, 592-606. http://dx.doi.org/10.1111/j.1365-313X.2006.02980.x

[80] Liu, P.P., Montgomery, T.A., Fahlgren, N., Kasschau, K.D. and Nonogaki, H. (2007) Repression of AUXIN RESPONSE FACTOR10 by MicroRNA160 Is Critical for Seed Germination and Postgermination Stages. Plant Journal, 52, 133-146. http://dx.doi.org/10.1111/j.1365-313X.2007.03218.X

[81] Liu, Q., Zhang, Y.C., Wang, C.Y., Luo, Y.C., Huang, Q.J., Chen, S.Y., Zhou, H., Qu, L.H. and Chen, Y.Q. (2009) Expression Analysis of Phytohormone-Regulated MicroRNAs in Rice, Implying Their Regulation Roles in Plant Hormone Signaling. FEBS Letters, 583, 723-728. http://dx.doi.org/10.1016/j.febslet.2009.01.020

[82] Jung, H.J. and Kang, H. (2007) Expression and Functional Analyses of MicroRNA417 in Arabidopsis thaliana under Stress Conditions. Plant Physiology and Biochemistry, 45, 805-811. http://dx.doi.org/10.1016/j.plaphy.2007.07.015

[83] Li, W.X., Oono, Y., Zhu, J., He, X.J., Wu, J.M., Iida, K., Lu, X.Y., Cui, X.P., Jin, H. and Zhu, J.K. (2008) The Arabidopsis NFYA5 Transcription Factor Is Regulated Transcriptionally and Posttranscriptionally to Promote Drought Resistance. Plant Cell, 20, 2238-2251. http://dx.doi.org/10.1105/tpc.108.059444

[84] Jia, X., Wang, W.X., Ren, L., Chen, Q.J., Mendu, V., Willcut, B., Dinkins, R., Tang, X.Q. and Tang, G.L. (2009) Differential and Dynamic Regulation of miR398 in Response to ABA and Salt Stress in Populus tremula and Arabidopsis thaliana. Plant Molecular Biology, 71, 51-59. http://dx.doi.org/10.1007/s11103-009-9508-8 